\title{
Considerations About European Directives and Italian Regulation on Sludge from Municipal Wastewater Treatment Plants: Current Status and Future Prospective
}

\author{
Claudia B. Rizzardini and Daniele Goi*
}

Dipartimento di Scienze e Tecnologie Chimiche, Università degli Studi di Udine, via del Cotonificio 108 - 33100 Udine,
Italy

\begin{abstract}
This work reports some reflections about the European and Italian regulation on sewage sludge. In Europe, the progressive augment of the production of sludge from municipal wastewater treatment plants has recently led to a growing attention about management of this type of solid matrix.
\end{abstract}

European Directives and Italian guidelines stimulated reuse of sewage sludge on agricultural soils or in composting factories encouraging the restitution to the biogeochemical natural cycles of recovered material. Nevertheless current Italian law on wastes suggests that sewage sludge must be subjected to the general regulation of waste and sometime public opinion suspect about the sludge recovery practice prevails on the convincement concerning a more convenient waste management.

Fundamental policy of constituting European Union regulation on sewage sludge promotes agricultural reuse when sludge has transformed according to conventional and advanced treatments, this means that a well defined and standardized norm for characterization and treatment is necessary.

In the year 2000, the $3^{\text {rd }}$ draft of "Working document on sludge" was developed with the aim to promote the use of sewage sludge in agriculture, to ensure safety of land application and to harmonize sludge quality standards. This document can be considered an optimum basis to develop further guidelines considering a new approach to the field.

The aim is to obtain without delay a final draft to introduce a European shared prospective in sewage sludge management which is every time stimulated and directed by certain and actual regulations.

\section{INTRODUCTION}

Last decade in Europe a progressive increase in production of sludge from municipal wastewater treatment plants (MWWTP) (from $8 \times 10^{6}$ tonnes in 1998 to $10^{7}$ tonnes in 2007) had been revealed and a continuous raise of the cost for landfill disposal has verified. Nowadays depending on both geographical localization and technologies of disposal, a range of charge from 380 to 750 euro per tonne (on dry mass basis) can be assumed [1]

In the municipal and industrial wastewater treatment plants, the separation of organic and inorganic particles by sedimentation and the treatment of biodegradable substances by biological technology, produce high quantity of primary and secondary sludge. Sewage sludge in a treatment plant contains a high fraction of water with a little percentage of solid material and, even after drying out, water can remain greater than $60-70 \%$ by weight. As a consequence a high volume of material must be managed to the final disposal with considerable costs.

Many researchers assume that the production of sewage sludge will increase in the next years because of treatment requirements connected to actual regulations (particularly in

*Address correspondence to this author at the Dipartimento di Scienze e Tecnologie Chimiche, Università degli Studi di Udine, via del Cotonificio 108 -33100 Udine, Italy; E-mail: goi@uniud.it
Europe) and new wastewater treatment plants constructions in emerging countries [1].

As a matter of fact European Directives and Italian guidelines, in the recent past, stimulated reuse of sludge from municipal wastewater treatment plants on agricultural soils or in composting factories. This perspective encouraged the restitution to the biogeochemical natural cycles of recovered material that, if considered only waste, could have heavy ecological and economic costs to disposal in landfill or in thermo-destructive plants [2]. Furthermore, the demand of preserving carbonious supply and fertility elements for the soils, together with a more convenient waste management prevailed on the public suspect (sometime strong opposition) about the sludge recovery practice.

As an example in Italy the first frame regulation on wastes (D.lgs 5 February 1997, Nr. 22) [3] tagged sewage sludge as a type of waste considered for material recovery (Annex I, art.3). In this regulation, sewage sludge was classified as "special waste", dangerous or not dangerous (art.7) and specific CER (European Waste Catalogue) codes were introduced to identify it (the code 190000 is referred to waste from waste treatment, wastewater treatment plant out of site and water industries, Annex A).

New Italian regulation (D.Lgs. 3 April 2006, Nr. 152, also known as the "all comprehensive law about the environment", D.Lgs.152/2006) [4] is based on concepts ob- 
tained from the previous guidelines: it pursues first the priority of prevention and reduction of both waste production together with its danger, than the recovery (of energy and material). Common waste disposal (landfilling or incineration) is intended at last with a second order of concern.

Given the statements of the Italian regulation about the agricultural reuse (D.Lgs. 27 January 1992, Nr. 99) [5], the current regulation on wastes suggests that sewage sludge from wastewater treatment plants must be subjected to the general regulation of waste, where it is applicable, and in particular when the sludge has to be considered a residue at the end of the complete process of the wastewater treatment plant (art.127). The last upgrade of the mentioned guideline (given by the D.Lgs. 16 January 2008, Nr. 4; art. 2, paragraph 12-bis) [6] underlines the opportunity of reutilization of sewage sludge only if the reuse is appropriate and sewage sludge is recovered as new raw material.

The European Union has regulated disposal and use of sewage sludge in agriculture through several directives that established consistent quality requirements for the environment, some of these are: the Council Regulation (EEC) $\mathrm{Nr}$. 2092/91 of 24 June 24th 1991 on organic production of agricultural goods, the Directive 1999/31/EC on the landfilling of waste, the Commission Decision 2001/688/EC for the award of the Community eco-label to soil improvers and growing media (revised by Commission Decision of 15 December 2006). However, the most important European guideline is the Council Directive 86/278/EEC of 12 June 1986 on the protection of the environment (specifically of the soil), when sewage sludge is used in agriculture [7].

This act introduces quality standards for soil and sewage sludge when they are applied in agricultural terrain with the aim to regulate their correct use and to prevent probable harmful effects on soil, vegetation, animals and humans.

In particular, this directive introduces specific requirements about concentration of heavy metals, kinds of treatment to apply and analyze to carry out on sludge and soil before application. Furthermore, it specifies areas where the use of sludge is prohibited (art. 7): on grassland or forage crops, on fruit and vegetable crops during the growing season (with the exception of fruit trees) and on ground intended for the cultivation of fruit and vegetable crops which are normally in direct contact with the soil and normally eaten raw (for a period of ten months preceding the harvest and during the harvest itself).

The use of sewage sludge must ensure preservation of soil, surface and ground water in compliance with both aged Directives 74/440/EC (concerning the required quality of surface waters designated for the production of drinking water) and 80/68/EEC (on the protection of groundwater against pollution caused by certain dangerous substances).

As a matter of fact, the Council Directive 86/278/EEC reached, above all, the target to assess guidelines of Member States to avoid difference in utilization of sewage sludge for agricultural purposes and it balanced possible strains on the global sludge market.

The basic European instructions on sludge management took also into account also on Council Directive 91/271/EEC [8] (concerning wastewater treatment, also known as the
"Urban Wastewater Treatment Directive"). This fundamental directive was included into Italian D.Lgs. 11 May 1999, Nr. 152 (provisions on the protection of water against pollution following Council Directive 91/271/EEC concerning urban wastewater treatment and Council Directive 91/676/EEC concerning the protection of waters against pollution caused by nitrates from agricultural sources, also known as the Nitrates Directive) and recently rearranged into the above mentioned D.Lgs. 152/2006. The Council Directive 91/271/EEC aimed to protect the environment from the adverse effects of wastewater discharges to water recipients and its observance in last decade brought to an increase of urban sewerage systems and wastewater treatment plants over all European area. As a result the annual production of sewage sludge increased significantly in all EU Member States.

A recent commission report (July 2006) on the implementation of community waste legislation in the field confirmed that most EU-15 Member States registered a growth of sludge production in the period 2001-2003. Seven Member States reported that at least $50 \%$ of the sludge was recovered for agriculture use and their national regulations forced this objective [9].

On the other hand in several Member States the decreasing use of sewage sludge in land application could be explained by the growing apprehension of the public opinion about the safety of the agricultural reuse. The report also persuaded again that the use of sewage sludge as fertilizers on rural soils remained one of the best environmentally tolerable disposal options if alertness to the environment and animal as well as human health was demonstrated.

In any case many European countries had decided alone concentration limits of some harmful substances below those specified in the Directive. Indeed, in some situation individual State data check demonstrated that average concentrations of heavy metals in sludge used in agriculture were significantly lower than those specified in regulations.

About 10 years ago a critical revision of the Directive 86/278/EEC was planned in order to accomplish some new targets in sludge recovery question and to improve the existing situation about sludge management, starting from the principles declared in Article 175 of the EC Treaty on environment protection [10]. As a result in the year 2000, the $3^{\text {rd }}$ draft of "Working document on sludge" was developed and published by European Commission's Environment Directorate-General with the aim to promote the use of sewage sludge in agriculture, to ensure safety of land application and to harmonize sludge quality standards. In this document the sludge from MWWTP is also defined as sewage sludge, distinguishing septic sludge and industrial sludge as sludge from domestic and industrial wastewater, respectively [11].

\section{MANAGEMENT OF SLUDGE FROM MWWTP}

Currently, treatment and disposal of sewage sludge have become an important issue of the European waste framework, first of all because of increasing limitation to waste disposal in the landfills and also following serious wasterelated episodes happened in some countries (such as problematic urban waste management in Italy).

The Council Directive 1999/31/EC [12] on the landfill of waste excluded the disposal of liquid waste (e.g. sludge) to 
landfills giving a restriction to the general sewage sludge management. This Directive intended to reduce the quantity of biodegradable waste going to landfills and discouraged the landfilling of both liquid and untreated wastes. Consequently, the disposal of sludge to landfills should be in the long run eliminated.

In Italy this Directive was introduced by D.Lgs. 13 January 2003, Nr. 36 and a delay till 2008 (December $31^{\text {th }}$ ) was immediately approved for its application [13].

This law gives a lot of rules regarding final waste disposal in landfills but it doesn't provide suggestions to the solution of the sludge management problem (art.3, paragraph 2a).

In this context a discussion is open about the study of new chemical, physical or biological sludge treatment technologies focused on minimizing production of sludge, starting from the process where it is produced to the final disposal. In this way the unhealthy idea to shift sludge management problems from a water pollution concern to an affair of solid waste disposal only could be prevented.

Sludge from MWWTP is traditionally managed in different ways but four main practices are well known:

1. Disposal into landfill:

According to the Directive 1999/31/EC landfill is a "waste disposal site for the deposit of the waste onto or into land". This Directive establishes measures, directions and guidance in order to prevent or reduce the adverse effect on the environment of landfilling of waste. In this regulation stringent operational and technical requirements concerning the waste and the landfilling are provided [14]. A landfill is a controlled, final and inert deposit for sludge as well as for other organic and inorganic matrices. The site of landfilling can be considered as a final deposit of a sludge or waste in which it is entrapped and controlled sometimes even via inertization by minerals (such as cements and clays) or organic ligands (such as resins and chelants). By this method some particularly hazardous compounds present in the sludge are entrapped and their release is prevented.

The currently accepted guidelines on MWWTP sludge management in Europe accounted as primary hazardous pollutants in sludge only heavy metals but virtuous sludge managers are reflecting on other particular organic compounds. Landfilling of sludge engages several difficulties, mainly due to sludge physical consistency and chemical quality. In any case landfilling is a necessary support to all other waste handling procedures in order to assure the final disposal of materials not available for reutilization and during emergencies [15];

2. Incineration:

This practice is disciplined by the Directive $2000 / 76 /$ EC on the Incineration of waste, accomplished in Italian law by the D. Lgs. 11 May 2005, Nr. 133. It establishes severe needs for air pollution quality coming from waste incinerators, consequently only specific technologies with high quality effluent characteristics turned out to be effective in sludge waste management [14]. This solution is usually adopted for sludge with a high organic content and low humidity, besides thermal process must be performed by particular furnaces where it can be achieve the reduction of volume and weight of waste, the abatement of toxic organics and the recovery of energy. The co-incineration of the sludge together with other wastes is also adopted. Sludge material with high organic content could be also entered in the renewable energy production chain by thermal and biological transformation. As an example, a number of advanced thermal conversion technologies (e.g., supercritical water oxidation process and pyrolysis) are under development for sewage sludge management with the aim to generate energy-related products, such as higher quality fuels and recovery of phosphorus [16]. The thermal destruction of sludge by incineration requires a careful economic evaluation but generally, where the distance from agricultural territory or landfill sites yields to prohibitively expensive transport (e.g. in large urban areas), it could be a cost-effective solution [15];

3. Recovery:

In sludge management the recovery of solid matrices can be accomplished by several methods. Selected inorganic sludge can be mixed with clays, cements or other materials in building works to obtain fluffy aggregates, particular bricks or joining tiles.

Several thermal solidification processes have been developed mainly in Japan to assure high quality of the end products. The Japanese experience proves that all the processes are technically feasible, but not economically: their manufacturing cost is always higher than market price and they spend considerable amounts of energy. These processes can be appraised if they are accredited for sludge disposal, in particular when the end products can be reused near the sludge producing area. For example, an interesting alternative is depicted in a recent research work in which sludge in "Portland cement" producing process is examined. A Portland cement company receives sewage sludge under payment but this is significantly cheaper than the cost of thermal solidification; in addition some importance about sludge management decisions has the distance between the sewage plant and the Portland cement plant [17].

Another and more appreciable solution is the recovery of organic sludge: it can be leavened together with other organic waste in order to obtain compost to use in agriculture. Anaerobic digestion is generally a more effective method than incineration for energy recovery and digested sewage sludge is suitable for further beneficial use through land application [16].

4. Direct recovery in agriculture through land application:

Some effective agronomical quality of sludge with high organic content is recognized only after treatment and under specific safety requirements. Nevertheless direct land application remains the most im- 
portant alternative for sewage sludge disposal, in particular for sludge produced by small or medium size wastewater treatment plants, with minor pollution by hazardous compounds and located close to the disposal site [15]. Land application of treated sewage sludge can lead to a complete reuse of its nutrients and organic carbon at a relatively low cost. Therefore, this practice should become a preferred management option where there is available land, the quality of sewage sludge meet regulatory requirements, and it is socially acceptable. Intensive energy cropping and forest production using biosolids can also help us to meet the ever-increasing demand for renewable energy (e.g. biomass power and biomass heating) [16].

As above noted, at the present time in Italy the agricultural use of sewage sludge is disciplined by a specific guideline: the D. Lgs. 27 January 1992, Nr. 99 (D. Lgs. 99/92) derived from key Directive 86/278/EEC. This regulation influences the sludge management given that deals with some important topics:

1. Concentration limits for heavy metals in both sludge and soils;

2. Agronomical and microbiological characteristics of sludge;

3. Maximum amount of sludge for land application.

According to data reported more than ten years ago, agricultural use of sludge in Italy was scarce: only $18 \%$ of the total wastewater treatment sludge produced was utilized in agriculture and almost entirely in the North or Central area of the country. During the same period $80 \%$ of this sludge was disposed into landfills and, due to strong opposition of the public opinion against incineration, only $1 \%$ of the sludge was managed by this method. For the following years a great reduction of landfill disposal and an augment of agricultural recycling of sewage sludge were foreseen [14]. In fact, data collected by the Italian Environmental Administration in the period 2001-2003 already showed a growing percentage of land application near to $32 \%$.

This target, stimulated by the Directive 1999/31/EEC, was probably reached following imperative reduction of biodegradable municipal waste and other organics requested in landfill disposal. Nevertheless this increase of sludge recovery was also motivated by some financial measures like the ecological tax [18].

The last Italian Report on Waste 2007 [19] (corresponding to the period 2003-2005) reveals some ambiguous and rather not complete data. From one side it highlights a significant reduction of the wastewater treatment plant sludge production (from 1.463.679 to 337.267 tonnes per year), but to the other side the percentage increases (from $5.12 \%$ to $24.7 \%$ ) of waste disposal in landfill is ascertained. The same data report shows a substantial decrease of land application (from $30.8 \%$ to $19.25 \%$ ) and an improvement of sludge managed by incineration and composting.

The same report states that there are many disperse treatment units currently operating in Italy and the typical plant has a capacity lower than 10.000 equivalent inhabitants. As a consequence there is a need of reduction and unification of small treatment plants to improve efficiency of the whole depuration system as well as the sludge management.

Actually, fundamental policy of constituting European Union regulation on sewage sludge encourages its agricultural reuse when it has been transformed according to available conventional and advanced treatments (primarily hygienisation) [11]. Moreover, European guidelines consider land application as a potential and helpful perspective for waste management and disposal, considering that this material would be able to improve or replace fertilizers and manures with good agronomic value and minor cost [20].

The use of safe sewage sludge as a fertilizer maintains an advantageous potential for matter recycling with the aim to prevent the progressive loss of organics and nutrients in the soil which could get worse in case of sludge landfilling or incineration. Nevertheless, sludge must be used on land only whenever possible according to appropriate Community or National legislation with particular regard to harmful pollution [11].

\section{KEY POINTS OF ITALIAN REGULATION ABOUT SEWAGE SLUDGE AGRICULTURAL UTILIZATION}

According to Article 2 of Directive 86/278/EEC "Sludge" is defined as:

1. Residual sludge from sewage plants treating domestic or urban wastewaters and from other sewage plants treating wastewaters of composition similar to domestic and urban waste waters;

2. Residual sludge from septic tanks and other similar installations for the treatment of sewage;

3. Residual sludge from sewage plants other than those referred in (1.) and (2.) provided that its use is regulated by the Member State concerned.

The term "sewage sludge application" in agricultural activities should be intended the spreading of manures or any other part of a treated solid matrix, on or into the soil. The use on terrain of sludge type 1 and 2 is permitted when Member State regulations about protection of human and environmental safety (art.3) are respected.

As before observed in Italy the Directive 86/278/EEC was introduced by the Decree D.Lgs 99/92. This regulation identifies sewage sludge as waste material coming from domestic wastewater (referring to definition of Directive 91/271/EEC about domestic and similar wastewater), or from a mixture of domestic and industrial wastewater (when composition is similar to or assimilated to sludge mentioned above), or also from industrial wastewater when sludges are similar to the other kind amenable for agricultural utilization (art. 2, paragraph 1.g of D.Lgs. 99/92 and art. 74 of D.Lgs. 152/06).

The use of toxic and harmful sludge is explicitly prohibited and the exclusion of the sludge recovery is underlined when the sludge contains some substances (art. 4, paragraph 2).

Member States can adopt regulations stricter than those in Directive 86/278/EEC or they can apply more conditions (art. 12); in fact D.Lgs 99/92 permits sludge agricultural use following specific requirements: 
1. Sludge must be subjected to biological, chemical or thermal treatment, by a long period deposit or by another appropriate process so that a substantial decrease of fermentation potential and land application hazards can be demonstrated (art 2, paragraph 3);

2. Sludge must be suitable for a manure, amending and/or corrective effect on soil;

3. In sludge the absence of toxic, harmful and/or persistent and/or not biodegradable substances in such concentration to be harmful for soil, crops, animals, man and environment must be verified (art. 3, paragraph $1)$.

Soils for agricultural application must have specific prerequisites too. In particular a cation exchange capacity (C.E.C.) greater than $15 \mathrm{meq} / 100 \mathrm{~g}$ and a $\mathrm{pH}$ range between 6,0 and 7,5. Furthermore, a quantity of sewage sludge not greater than 15 tonnes (dry matter) per hectare can be spread over the terrain in a three-year period; this amount can be halved or doubled up if above cited chemical requisites are not ensured (art. 3, paragraph 4). Sewage sludge from agro and food industry can be applied in a quantity up to three times higher than the value recommended.

Sewage sludge application to soil is generally permitted when the natural presence of heavy metals is not high and the analytical examination must be performed on both sludge and soil. Italian regulation considers concentration limits more stringent than those suggested by Directive $86 / 278 /$ EEC except for nickel and zinc relative to soil. In this case heavy metals have first to be controlled in both sludge and soil, than the soil must be check after the sewage sludge application (art. 3, paragraph 2 and 3).

These guidelines require the analytical control and the quality certification of solid matrices by mean of methods of sampling and analysis which are to be defined by Italian Ministry of Environment together with the Ministry of Agriculture and Industry (art. 5, paragraph 1); waiting for these rules the best available technologies-methods have to be applied (Annex II A, art. 2, paragraph 7).

When sludge is suitable for agricultural use, D. Lgs. 99/92 establishes that samples must be analyzed whenever there are significant changes in the quality of treated wastewater and periodic analytical sludge characterization have to be performed in accordance to plant potentiality (art. 11, paragraph 1): every three months in plants with capability higher than 100.000 equivalent inhabitants, every six months with plant capability lower than 100.000 equivalent inhabitants and at least one characterization during a year when plant capability is lower than 5.000 equivalent inhabitant.

When sewage sludge is stored, mixed, treated and/or amalgamated with chemicals, it must be further analyzed before application to verify the respect of the maximum values suggested in Annex I B of this law.

Analytical assays must be done only in public laboratories or moderately in private ones which must have obtained particular official recognition by Italian Government (art. 11, paragraph 5). Similarly, the company that is authorized to use sewage sludge must provide soil characterization by public or private laboratories with a periodicity of at least three years (art. 10, paragraph 1 and 2).
Although D.Lgs. 99/1992 establishes maximum quantity of sludge to spread yearly over the soil (amount for surface unit) according to Directive 86/278/EEC (art. 5, paragraph $2 \mathrm{a}$ ), the guideline is not clear when it specifies the respect of heavy metal limits considering the concentration per surface unit and the amount in ten years average time (art. 5, paragraph b).

The law underlines some necessary and obligatory awareness for protection of soil, vegetation and animals when sewage sludge has to be used in agricultural terrain, further it established when land application is prohibited for reasons concerning (art. 4):

1. Characteristics of soil: the prohibition deals with degree of saturation of soil (flooded soils or marshy or with an emerging water - bearing stratum or with active landslides), morphology (in case of sewage sludge with dry matter content lower than $30 \%$ the spreading is prohibited if the soil has a slope over $15 \%$ ), $\mathrm{pH}$ values (application prohibited if $\mathrm{pH}$ lower than 5) and cation exchange capacity (application prohibited if lower than $8 \mathrm{meq} / 100 \mathrm{~g}$ );

2. Soil destination: regarding the grassland, meadow pasture or forage crops, together with other crops, land application is banned 5 weeks before pasturing or foraging; this prohibition arrives at 10 months for grounds intended for the cultivation of fruit and vegetable crops; the interdiction is permanent for soils in which ground fruit and vegetable crops are growing, with exception of arboriculture;

3. Spreading technologies: land application of semidry or liquid sewage sludge is forbidden by means of sprinkling.

Certainly, in Italy during ' 80 s and ' 90 s, land applications of sludge were often massive and subjective; sometimes the regulation was complied following mainly technical and administrative requirements. D.Lgs 99/92 introduced only a basic characterization of sewage sludge and a minor analytical control charge defined substantially by plant potential (art.11, paragraph 1), besides the monitoring of soil quality interested by land application was limited to an approximate characterization (art.10, paragraph 2), nevertheless some additional innovation was appearing in research studies, public attention and consciousness of some administrators and managers.

\section{EUROPEAN UPDATED GUIDELINES ON USE OF SEWAGE SLUDGE IN AGRICULTURE}

By the Directive 86/278/EEC and successive developments a new approach to the quality and management of sewage sludge was introduced, it paid particular attention to composition and potential pollution by persistent hazardous compounds coming both from industrial wastewater effluents and domestic waterborne activities (also reflecting better about of pharmaceuticals, personal hygiene substances and other synthetic compounds).

It is well known that even if sewage sludge adds to the soil precious and nutritive substances like organic matter, nitrogen and phosphorus, it often contains heavy metals and organic contaminants such as PAH (Polycyclic Aromatic 
Hydrocarbons), PCB (PolyChlorinated Biphenyls) and dioxins which can cause severe pollution of the soil.

The presence of these substances gets worse the overall sludge quality and reduces its potential use in agricultural practices which are effectively related to environment and, as a final point, to human health. Moreover, some refractory organic pollutants are difficult to degrade by means of traditional sludge treatments close to the MWWTP, so they can reach the soil-ground environment leading pollution to groundwater and also interfering with quality and evolution of sewage sludge natural stabilization (for instance limiting evaporation or expected bioprocesses) [2].

As previously noted, in the year 2000 the $3^{\text {rd }}$ draft of "Working document on sludge" was developed with the aim to promote the use of sewage sludge in agriculture, to ensure safety of land application and to harmonize sludge quality standards [11].

This document introduces reasoned maximum values for concentration of heavy metals and organic compounds in sludge; as a result restrictions of the use of sewage sludge in agriculture and suggestions for optimal treatment practices in land application are provided. It must be underlined that, already during the ' $90 \mathrm{~s}$, some European States established limits for several organic compounds found in sewage sludge suitable to be applied to land and these limits were similar or more severe to those suggested by new "Working document on sludge".

Generally, in this regulation upgrade, a difficulty to select organic contaminants and to set up maximum values of the limits can be perceived; these facts could be ascribed to the detection of such pollutants (sometimes expensive laboratorial equipments need to identify trace organic micropollutants) and also to the fact that there are potentially thousands of organic compounds to analyze and new substances are continuously introduced in the sludge-related environment. As a matter of fact, little experience and approximate data about organics in sewage sludge are currently available, so the study of the interactions regarding sludge, soil, plants and micro pollutants remains fundamental.

The "Working document on sludge" also suggests internationally accepted standard methods to analyze pollutants in sludge, in particular the use of CEN (European Committee for Standardization) and ISO (International Organization for Standardization) norms are appreciated. If CEN standards are not yet available, ISO or national standards have to be preferred ("Working document on sludge" - Annex VII). By this approach, comparison and monitoring of data are assured and, moreover, public communication of risk bound to management of this kind of waste becomes less problematic.

The topic of sludge quality measurement has always been recognized important. In November 1999, the Directorate General of the Environment and the Joint Research Centre of the European Commission had already organized a workshop on "Problems around sludge"; this meeting was followed by another discussion conferences in 2001 on "Harmonization of analytical methods of sampling and analysis methods for heavy metals, organic pollutants and pathogens in soil and sludge". Besides in December 2002 the "Project Horizontal" started with the aim to develop horizontal and harmonized European standards in the field of sludge, soil and treated biological waste [21]. By this proposal the application of guidelines to manage characterization of these solid matrices became facilitated.

The mission of the project was the evaluation of the feasibility and the development of a "horizontal standard" or various "horizontal standards" in the field of sludge characterization. This aims to standardize sludge sampling, analytical measure of biological, hygienic, organic and inorganic parameters, as well as mechanical properties and leaching behavior of sludge, soil and other treated biological wastes. Moreover, to ensure appropriate discussion, reports were provided on the web in favor of all the interested organizations (such as CEN and ISO Technical Committees, Sub committees, Working groups and Task groups, National Standardization Bodies and National mirror committees) and end users.

Finally, it is important to underline that the "Working document on sludge" was programmed mainly to propose recommendations for Member States and these guidelines are not still approved or incorporated in every National Regulation [14].

\subsection{Future Potential of Sewage Sludge Land Application in the Light of "Working Document on Sludge $\left(3^{\text {rd }}\right.$ Draft)"}

The "Working document on sludge" opens new prospective about the sludge characterization, treatment and management, some of them are worth to be noted.

In a different way, respect to Directive $86 / 278 / \mathrm{EEC}$, the document extends the sphere of application of sewage sludge to green areas, parks, city gardens and all other similar public areas on condition that sludge is well stabilized and odorless. Nevertheless, the "Working document on sludge" has introduced some limitations.

For example, it prohibits explicitly the sludge application in forests, also following the aim of the Convention on the Protection of the Alps that had established to give up application of sewage sludge as soil conditioning on Alpine territory, in order to guarantee the preventive protection of this area [22]. Member States can approve the use of sludge in plantations (short-rotational plantations, plantations for growing energy crops, Christmas tree plantations and similar) and for re-forestation purposes on condition that plant nutrient needs are verified and sludge-waste is located without risk for human health and environment (concept already specified in the article 4 of old Directive 75/442/EEC).

The new "Working document" pays also more attention to the geomorphologic land characteristics in order to prevent terrain run-off and soil compaction; moreover it suggests to avoid the production of aerosol as well as unreasonable odor nuisances.

From crop growing point of view, the document wonders about real requirement of the plant in terms of nutritional needs and organic matter provision. It recommends a reliable correspondence between demand of the crop and sludge application, as well it highlights the need of an optimal evaluation of the global nutritive balance related to other concurrent amendment procedures as mineralization and input of fertilizers. 
The document introduces more stringent limits for heavy metals concentration in soils (expressed depending on $\mathrm{pH}$ ) and a threshold maximum value for chrome (Annex II).

A different prospect to rules given in the Directive 86/278/EEC, the draft authorizes the use of sludge also when the concentration value of a single heavy metal in a specific land area is higher than the permitted concentration limit; in that situation the regional environmental authority allows the ground application of sludge on a case-by-case basis and after evaluation of the following features: uptake of heavy metals by plants, intake of heavy metals by animals, as well as groundwater contamination and long term effects on biodiversity, in particular on soil biota.

When sludge utilization is employed in areas with higher heavy metal concentration, the document suggests to the competent authority the regular monitoring of the terrain together with the assessment of the risk of sludge disposal practice.

The "Working document" recommends new concentration limits for pollutants in sewage sludge. These values are sometime more severe and they are expressed both in a dry matter and total phosphorus content basis. In truth, another concept for heavy metals measurement is proposed because expression in term of dry matter is only recognized incomplete (Revision of Council Directive 86/278/EEC on the use of sewage sludge in agriculture", 2001/C14/26) [23]: heavy metal concentration can be diluted by mixing sludge with silt, sand, clay and manures; the treatment of sludge by composting or digestion results in a higher heavy metal concentration per dry matter; the simple quantification of heavy metals in sludge on dry matter basis does not furnish functional information about material provenience and characteristics.

The maximum value of heavy metals concentration in soil must be respected also when an exceptional and abundant spreading of sludge is requested for organic content amendment and biological activity improvement. Zinc and Copper can be added to the soil in higher concentrations but Environmental Authorities must demonstrate the specific need in the area.

The wide-ranging of environmental protection theme regarding the "Working document on sludge" is evidenced by the introduction of a time schedule for heavy metals concentration limits in the middle (2015) and long (2025) period, both for sludge (expressed as $\mathrm{mg} \mathrm{kg}^{-1}$ Dry Matter) and soil (expressed as grams per hectare per year, as maximum annual charge, calculated on a 10 -year average basis).

\subsection{Hazardous Organics in Sewage Sludge}

The "Working document on sludge" gives imperative exclusion of the land application when one or more established hazardous organics exceed the proposed limits. The aim of the document was to introduce standardization in organic parameters chosen in analytical methods.

From the point of view of the characterization of the solid matrix some interesting organics are presented in the document.

1. "AOX" (Sum of Halogenated Organic Compounds): this is a global parameter that represents the sum of halogenated organics in the sludge. In effect the halorganic charge in the sludge can be a sum of purgeable (or "volatile") adsorbable and extractable organic halogen compounds. In the analytical methods for water this sum is usually evaluated by the respective global parameters (POX: Purgeable Organic Halogen, AOX: Adsorbable Organic Halogen and EOX: Extractable Organic Halogen), nevertheless specific and standardized procedures need for determination of global content of organic halogens in solid matrices. However, among the others EOX (Extractable Organic Halogen) can be a useful parameter in the characterization of global halorganic pollution in sludge, even if only a few experiences are reported about this characterization [24]. If the "Sum of Halogenated Organic Compounds" is considered as a list of single halorganic compounds, then it must be specified how many and what kind of substances are to be examined. For example, some typical "not purgeable" halorganic pollutants can be representatives of the "AOX": Aldrin, Biphenyl, o-Phenylphenol Chlordane, Dieldrin, Endrin, Heptachlor, DDT [1,1,1trichlor-2,2-bis(p-chlorphenyl)ethan], lindane, $\mathrm{HCH}-$ isomers, [hexachlorcyclohexan], hexachlorobenzene, hexachlorobenzol, heptachlor, pentachlorophenol, pyrethroides, Thiabendazole [25]. It must be also noted that in recent past some Member States (Austria and Germany) have already introduced limits for halogen compounds in sludge in order to prevent local ground pollution [26]. In the "Working document on sludge ( ${ }^{\text {rd }}$ draft)" "AOX" limit value proposed is $500 \mathrm{mg} / \mathrm{kg}$ $\mathrm{dm}$ (maybe an excessive or incorrect high value).

2. LAS (Linear alkylbenzene sulphonates): more than 10 years ago (1996), Denmark has introduced regulation limits for this parameter together with other restrictions on concentration of DEHP (Di (2-ethylhexylphthalate), NP/NPE (nonylphenol-nonylphenolethoxylates) and PAH (Sum of polycyclic aromatic hydrocarbons) even more stringent of that proposed now in the "Working document". This regulation has been established by Danish Environmental Government with the aim to assure safety of food and groundwater when terrain was amended with sludge.

3. PAH (Sum of polycyclic aromatic hydrocarbons) and PCB (sum of polychlorinated biphenyls): for these parameters some Member States that have regularized the land application of sludge have suggested regular limits, in many cases the value of the limits was more severe than that planned in the "Working document". In particular, in France a great attention was given to soils amended with sludge and used for grazing purposes, in this State a serious awareness was recognized for PAH brought by sludge within ten-years of application.

4. PCDD/F (Polychlorinated dibenzodioxins/dibenzofuranes): these are among the most important parameters for their health and environmental concern, the "Working document on sludge" makes clear once at all the impact on these compounds on sewage sludge management. 
About these and other new characterization parameters, in Italy some interesting studies have been carried out at a regional level with reference to the "Working document on sludge" $[27,28]$.

\subsection{Hygienic and Sanitary Concern of Sewage Sludge}

The Directive 86/278/EEC on the use of sewage sludge in agriculture does not recommend particular attention about pathogenic microorganisms however, corresponding Italian law introduces in D.Lgs 99/92 a maximum permitted limit for Salmonella setting up a value of $10^{3} \mathrm{MPN} / \mathrm{gSS}$ (usually CFU/100 ml). The Directive plan confides that every Member State exercises by their own particular and optimal caution in agricultural sludge spreading procedures and takes firm vigilance about environmental and health sanitary problems.

New "Working document" suggests more attention to basic sanitary practices of sewage sludge management and it proposes technological solutions to limit dispersion of pathogens in the environment and to improve farming customer assurance.

Sewage sludge must attend two possible treatments before soil application (Annex I) as described in Table 1:

1. Conventional treatments;

2. Advanced treatments defined hygienization.

A different prospect to Directive 86/278/EEC "Working document on sludge" excludes land application for sewage sludge not arranged by one of the mentioned treatments. Further it establishes that sludge from septic tanks, cesspools and other sludge producing installation should be handled to a wastewater treatment plant for further treatment before use.

The two kinds of treatment processes should be validated by a minimal: Escherichia coli reduction of no less than $2 \operatorname{logs}$ and $6 \operatorname{logs}$ in a conventional treatment and hygienization, respectively.
Other important sanitary-related requirements documented in the draft are the Salmonella $S p$ absence and the whole control of quality parameters that should be performed preferably every day.

Regarding the process control and analytical monitoring, it must be noted that many procedures and European standards are still to be scheduled and harmonized [21], nevertheless future development of the sewage sludge management will depend a lot from the treatment and handling of these solid matrices.

\section{CONCLUSION}

At the present time the situation about management of sewage sludge from municipal wastewater treatment plants in Europe is not clearly defined and regulations are to be considered in progress. European Commission rules seem substantially to encourage the use of sewage sludge in agriculture because they consider minor the risk to vegetal, animal and human safety and they appear to be confident that such practice sufficiently guarantees environmental protection [27].

This assumption looks weak, some Member States already limit the use of sewage sludge (e.g. Sweden since 1999) and some other countries prohibit land application (Switzerland and many Länders of Germany) [1]. Obviously in this case they adopt and encourage other types of disposal (e.g. incineration or landfilling), which produce unavoidably several other impacts on both environment and human health (increase in emission of greenhouse gases such as $\mathrm{CO}_{2}$ and $\mathrm{CH}_{4}$, major energetic use and disposal cost, land consuming etc...).

In effect management of sewage sludge appears a complicated theme, which includes different areas of interest and needs an interdisciplinary approach with reference to agriculture, environment and public health. Also society opinion plays an important role: both legislative definition and current terminology perceive sewage sludge as a waste, so it is difficult to depict it as a resource.

Table 1. Sludge Treatment Processes Suggested by "Working Document on Sludge"

\begin{tabular}{|c|c|}
\hline Conventional Treatments & Advanced Treatments (Hygienisation) \\
\hline $\begin{array}{c}\text { Thermophilic aerobic stabilisation at a temperature of at least } 55^{\circ} \mathrm{C} \text { with } \\
\text { a mean retention period of } 20 \text { days }\end{array}$ & $\begin{array}{l}\text { Thermal drying ensuring that the temperature of the sludge particles is higher } \\
\text { than } 80^{\circ} \mathrm{C} \text { with a reduction of water content to less than } 10 \% \text { and maintaining } \\
\text { a water activity above } 0.90 \text { in the first hour of treatment }\end{array}$ \\
\hline $\begin{array}{l}\text { Thermophilic anaerobic digestion at a temperature of at least } 53^{\circ} \mathrm{C} \text { with a } \\
\text { mean retention period of } 20 \text { days }\end{array}$ & $\begin{array}{c}\text { Thermofilic aerobic stabilization at a temperature of at least } 55^{\circ} \mathrm{C} \text { for } 20 \text { hours } \\
\text { as a batch, without admixture or withdrawal during the treatment }\end{array}$ \\
\hline $\begin{array}{l}\text { Simultaneous ambient-temperature aerobic stabilization concerning a } \\
\text { process performed in a limited time which is specified by the competent } \\
\text { authority following climatic conditions in the zone }\end{array}$ & $\begin{array}{l}\text { Thermophilic anaerobic digestion at a temperature of at least } 53^{\circ} \mathrm{C} \text { for } 20 \\
\text { hours as a batch, without admixture or withdrawal during the treatment }\end{array}$ \\
\hline $\begin{array}{l}\text { Conditioning with lime ensuring a homogenous mixture of lime and } \\
\text { sludge. The mixture shall reach a pH of more than } 12 \text { directly after lim- } \\
\text { ing and keep a pH of at least } 12 \text { for } 24 \text { hours }\end{array}$ & $\begin{array}{l}\text { Thermal treatment of liquid sludge for a minimum of } 30 \text { minutes at } 70^{\circ} \mathrm{C} \text { fol- } \\
\text { lowed by mesophilic anaerobic digestion at a temperature of } 35^{\circ} \mathrm{C} \text { with a } \\
\text { mean retention period of } 12 \text { days }\end{array}$ \\
\hline $\begin{array}{c}\text { Mesophilic anaerobic digestion at a temperature of } 35^{\circ} \mathrm{C} \text { with a mean } \\
\text { retention period of } 15 \text { days }\end{array}$ & $\begin{array}{l}\text { Conditioning with lime reaching a } \mathrm{pH} \text { of } 12 \text { or more and maintaining a tem- } \\
\text { perature of at least } 55^{\circ} \mathrm{C} \text { for } 2 \text { hours }\end{array}$ \\
\hline $\begin{array}{c}\text { Extended aeration at ambient temperature as a batch, without admixture } \\
\text { or withdrawal during the treatment period }\end{array}$ & $\begin{array}{c}\text { Conditioning with lime reaching and maintaining a pH of } 12 \text { or more for three } \\
\text { months }\end{array}$ \\
\hline $\begin{array}{c}\text { Storage in liquid form at ambient temperature as a batch, without admix- } \\
\text { ture or withdrawal during the treatment period }\end{array}$ & \\
\hline
\end{tabular}


The term "Biosolids" was introduced in USA by EPA (Environmental Protection Agency) to distinguish clearly the final product of the wastewater treatment plant from the treated sludge ready for soil application that "can be beneficially recycled" [29]. Different definition of "Bio-waste" was recently proposed by the European Commission to label some biodegradable waste such as biodegradable garden and park waste, food and kitchen waste and comparable waste from food processing plants, this category does not include forestry or agricultural residues, manure, sewage sludge and other biodegradable waste [30].

In truth, the key needed is a new adequate regulation with well specified definitions, limits and standardized procedures to realize potential of sludge recovery.

Whatever happens in next future the public opinion and the end user requirements should lead to adoption of more severe restrictions and more safe quality of sewage sludge to be recovered and reutilize.

European Community is elaborating guidelines and regulations through several projects that involve researches, regulatory agencies, end users, sludge and biowaste treating societies, CEN and ISO Technical Committees and others. These guidelines are in progress since a lot of time, but a final framework measure is expected, the aim is to reach without delay a new upgraded European Union Directive with instructions for product certification and standardized characterization.

\section{ABBREVIATIONS}

$$
\begin{aligned}
& \text { Art. }=\text { Article } \\
& \mathrm{CEN}=\text { European Committee for Standardization } \\
& \mathrm{CH}_{4}=\text { Methane } \\
& \mathrm{CO}_{2}=\text { Carbon dioxide } \\
& \text { D.Lgs. }=\text { Legislative Decree } \\
& \text { ISO }=\text { International Organization for } \\
& \text { Standardization }
\end{aligned}
$$

$\mathrm{meq} / 100 \mathrm{~g}=$ Term of expression for cation exchange capacity (CEC). It refers to the total number of cations a soil can hold (the amount of its negative charge) and it is expressed in terms of milligrams equivalent per 100 grams of soil (meq/100g)

MWWTP = Municipal wastewater treatment plants

\section{ACKNOWLEDGEMENT}

The authors are grateful to the C.A.P. spa (Consorzio Acquedotto Poiana) and Ing. Alessandro Patriarca for the suggestions and sustain in sewage sludge management studies.

\section{REFERENCES}

[1] G. Andreottola, P. Foladori and G. Ziglio, "Minimizzare i fanghi di depurazione. Strategie integrate nel trattamento delle acque reflue", Quaderni del Dipartimento, vol. SAN 6, pp. 13-16, Università degli Studi di Trento, March 2008.

[2] P. L. Genevini, "La tossicità dei fanghi di depurazione. Presenza di xenobiotici organici", Fondazione Lombardia per l'Ambiente, vol. 21, pp. 11-16, December 1996. Available: http://www.flanet.org/ download/publications/ricercherisultati/genevini.pdf [Accessed February 25,2008$]$.

[3] Decreto legislativo 5 febbraio 1997, n. 22 "Attuazione delle direttive 91/156/CEE sui rifiuti, 91/689/CEE sui rifiuti pericolosi e 94/62/CE sugli imballaggi e sui rifiuti di imballaggio". (Published on the ordinary supplement 33 of Italian GU February 15 1997, n. 38) Available: http://www.gazzettaufficiale.it/

[4] Decreto Legislativo 3 aprile 2006, n. 152 "Norme in materia ambientale". (Published on the ordinary supplement 96 of Italian GU April 14 2006, n. 88) Available: http://www.gazzettaufficiale.it/

[5] Decreto Legislativo 27 gennaio 1992, n. 99 "Attuazione della Direttiva 86/278/CEE concernente la protezione dell'ambiente, in particolare del suolo, nell'utilizzazione dei fanghi di depurazione". (Published on the ordinary supplement of Italian GU February 15 1992, n.38) Available: http://www.gazzettaufficiale.it/

[6] Decreto Legislativo 16 gennaio 2008, n. 4 "Ulteriori disposizioni correttive ed integrative del decreto legislativo 3 aprile 2006, n. 152 , recante norme in materia ambientale". (Published on the ordinary supplement of Italian GU Jenuary 292008 n.24) Available: http:// www.gazzettaufficiale.it/

[7] Council Directive 86/278/EEC of 12 June 1986 on the protection of the environment, and in particular of the soil, when sewage sludge is used in agriculture. Available: http://eur-lex.europa.eu/en/index. $\mathrm{htm}$

[8] Council Directive 91/271/EEC concerning urban waste water treatment. Available: http://eur-lex.europa.eu/en/index.htm

[9] Commission of the European Communities, "Report from the Commission to the Council and the European Parliament on implementation of the Community Waste Legislation - Directive 75/442/EEC on waste, Directive 91/689/EEC on hazardous waste, Directive $75 / 439 /$ EEC on waste oils, Directive 86/278/EEC on sewage sludge, Directive 94/62/EC on packaging and packaging waste and Directive 1999/31/EC on the landfill of waste for the period 2001-2003”, COM(2006) 406 final, pp. 6-7, July 192006.

[10] Treaty establishing the European Economic Community, EEC Treaty. (http://europa.eu/scadplus/treaties/eec_en.htm)

[11] European Commission, "Working document on sludge, $3^{\text {rd }}$ draft", April 27 2000. Available: http://ec.europa.eu/environment/waste/ sludge/pdf/sludge_en.pdf

[12] Council Directive 1999/31/EC of 26 April 1999 on the landfill of waste. Available: http://eur-lex.europa.eu/en/index.htm

[13] Decreto Legislativo 13 gennaio 2003, n. 36 "Attuazione della direttiva 1999/31/CE relativa alle discariche di rifiuti". (Published on the ordinary supplement of Italian GU March 122003 , n. 59)

[14] M. Loizidou, D. Malamis, S. Malamis, G. Xydis, and K. Moustakas, "Assessment of the existing situation and the related legislation in EU in connection sludge management", Design and Application of an Innovative Composting Unit for the Effective Treatment of Sludge and other Biodegradable Organic Waste in Morocco MOROCOMP LIFE TCY05/MA000141, pp. 30-81, May 2006. Available: http://www.uestgr/Morocomp/Progress.html

[15] L. Spinosa, "Evolution of sewage sludge regulations in Europe", Water Science and Technology, vol. 44(10), pp. 1-8, IWA Publishing 2001 .

[16] H.L. Wang, S.L. Brown, G.N. Magesan, A.H. Slade, M. Quintern, P.W. Clinton, and T.W. Payn, "Technological options for the management of biosolids", Environmental Science and Pollution Research, vol. 15(4), pp. 308-317, June 2008.

[17] N. Okuno, Y. Ishikawa, A. Shimizu, and M. Yoshida, "Utilization of sludge in building material", Water Sci. Technol., vol. 49(10), pp. 225-232, 2004.

[18] E. U. von Weizsäcker, and J. Jesinghaus, Ecological Tax Reform. A Policy Proposal for Sustainable Development Zed Books, London \& New Jersey, 1992: (http://esl.jrc.it/dc/etr/ecological_tax_reform. htm)

[19] APAT, "Il riutilizzo delle acque e dei fanghi prodotti da impianti di depurazione di reflui urbani: Quadro conoscitivo generale ed aspetti specifici”, Rapporto Rifiuti 2007, vol. 80, pp. 80-90, June 2007.

[20] European Commission for Environment. Available: http://ec.euro pa.eu/envi ronment/waste/sludge/

[21] Introduction Project Horizontal. Available: http://www.ecn.nl/hori zontal/

[22] Convention on the Protection of the Alps. Available: http://europa. eu/scadplus/leg/en/lvb/128161.htm 
[23] Economic and Social Committee, "Opinion of the Economic and Social Committee on «The revision of Council Directive 86/278/EEC on the use of sewage sludge in agriculture»", Official Journal of the European Communities, C14/26, pp.141-150, January $16,2001$.

[24] D. Goi, F. Tubaro, and G. Dolcetti, "Analysis of metals and EOX in sludge from municipal wastewater treatment plants: a case study", Waste Management, vol. 26, pp. 167-175, March 2005.

[25] Working Group Compost - Consulting \& Development (F. Amlinger, M. Pollack and E. Favoino), "Heavy metals and organic compounds from wastes used as organic fertilisers", Final Report ENV.A.2./ETU/2001/0024, July 2004

[26] H. Langenkamp, and L. Marmo, EUR 19809 EN "Workshop on harmonization of sampling methods for heavy metals, organic pollutants and pathogens in soil and sludge. 8-9 February 2001 Stresa
- Lago Maggiore - Italy. Summary and Conclusions", European Commission - Joint Research Centre, February 2001.

[27] G. Bortone, "Origini e motivazioni delle nuove determinazioni regionali sulla gestione dei fanghi di depurazione", Direzione Generale Ambiente Difesa del Suolo e della Costa - Regione Emilia Romagna, Convegno ATO, September 2007.

[28] P. Mantovi, and S. Piccinini, "I contaminanti organici nei fanghi di depurazione: sintesi dello stato dell'arte", RS Rifiuti Solidi, vol. 29(3), pp. 159-164, May-June 2005.

[29] D. Tenenbaum, "The beauty of biosolids", Environmental Health Perspectives, vol. 105(1), pp. 32-36, January 1997. Available: http://www.pubmedcentral.nih.gov/articlerender.fcgi?artid=146984 8

[30] Green Paper on the Management of Bio-waste in the EU, COM (2008) 811 final, \{SEC (2008) 2936\}, Brussels, 3.12.2008, Available: http://ec.europa.eu/environment/waste/compost/index.htm.

Received: December 31, 2008

Revised: January 22, 2009

Accepted: January 26, 2009

(c) Rizzardini and Goi; Licensee Bentham Open.

This is an open access article licensed under the terms of the Creative Commons Attribution Non-Commercial License (http://creativecommons.org/licenses/by$\mathrm{nc} / 3.0 /$ ) which permits unrestricted, non-commercial use, distribution and reproduction in any medium, provided the work is properly cited. 